\title{
Asymmetric Impact of Oil Prices and Stock Prices on Bank's Profitability: Evidence from Saudi Islamic Banks
}

\author{
Md Fouad Bin Amin ${ }^{1}$ \\ Corresponding email: fbinamin@ksu.edu.sa
}

Article History

Received : May 30 $30^{\text {th }}, 2021$

Revised : June $20^{\text {th }}, 2021$

December $1^{\text {st }}, 2021$

Accepted : December $10^{\text {th }}, 2021$

\begin{abstract}
The soundness of financial institutions including banks depends on both internal factors and external factors. The profitability of the banks largely affected by external shocks like oil prices and stock prices. As an oil-exporting country, Saudi economy particularly its banking sector largely rely on the oil prices. This study examines the asymmetric impact of oil prices and stock prices on Saudi Islamic banks' profitability for the period 2000-2020. Two Saudi Islamic banks' profitability is examined by the factors like Return on Equity (ROE) and Return on Assets (ROA) with the help of a nonlinear autoregressive distributed lag (NARDL) model. The estimated results are observed to be unbiased and robust. The results of this study show that OILP and STOCKP have significant role in determining the Islamic banks' profitability in Saudi Arabia. Both higher oil prices and stock prices have positive influence on ROE and ROA of Saudi Islamic banks. This study suggest that development and efficiency of Saudi stock market is important and macroeconomic policy should support the country's economic diversification. The management of Islamic banks need to focus on effective risk assessment and market monitoring tools to face the fluctuation of oil prices and their stock prices as these factors affect their profitability. Besides, Saudi Islamic banks need to diversify their investment portfolios into more productive and export oriented private sectors such as Small Medium Enterprises (SMEs). This strategic policy will enable Islamic banks to absorb any future shock of oil prices without affecting their profitability.
\end{abstract}

Keywords: Profitability; Oil prices; Stock price

JEL Classification: C32; 013; 016; E44

Type of paper: Research Paper

@ IJIEF 2022 published by Universitas Muhammadiyah Yogyakarta, Indonesia

DOI:

Web:

https://doi.org/10.18196/ijief.v5i1.11835 https://journal.umy.ac.id/index.php/ijief/article/view/11835

Citation

Amin, M. F. B. (2022). Asymmetric impact of oil prices and stock prices on bank's profitability: Evidence from Saudi Islamic banks. International Journal of Islamic Economics and Finance (IJIEF), 5(1), 31-58. DOI: https://doi.org/10.18196/ijief.v5i1.11835

\footnotetext{
${ }^{1}$ Department of Economics, Kind Saud University, Riyadh, Saudi Arabia
} 
Amin | Asymmetric Impact of Oil Prices and Stock Prices on Bank's Profitability: Evidence from Saudi Islamic Banks

\section{Introduction}

\subsection{Background}

A sound banking system is a prerequisite for the economic growth and development any economy (Habibullah \& Eng, 2006; Priscilla \& Ezeanyeji, 2019). Islamic countries mostly maintain dual banking systems i.e., conventional bank and Islamic bank (Massah and Al-Sayed, 2015). Islamic bank adopts Shariah principles and becomes a predominant player across the globe. Its performances outrun the counterpart and even proven resilient to face economic and financial crisis over the last few years (Tlemsani \& Al Suwaidi, 2016). One of the key factors behind this success of Islamic banks is because of their Shariah compliant products and services. It finances longterm and short-term development projects and experiences sustainable growth in most of the Islamic countries (Thorsten Beck, Demirgüç-Kunt, \& Merrouche, 2010; M. A. Hassan, Hafsa, \& Muhammad, 2011).

In Saudi Arabia, Islamic banking industry is well-developed which comprises of four Islamic banks, namely, Bank Al-Rajhi, Bank Al-Jazira, Bank Al-Bilad, and Bank Al-Inma. These banks aggregately possess $28.0 \%$ of total banking assets in the Kingdom. Al-Rajhi is the largest Islamic bank that owns $57.7 \%$ of the Islamic banking market share. In other estimation, the rest of three Islamic banks i.e., Al-Bilad, Al-Inma, Al-Jazira collectively hold $28.0 \%$ of total banking assets (Khan, Amin, Khokhar, Hassan, \& Ahmad, 2018). Despite the world economic uncertainty, Saudi Islamic banking industry had witnessed a remarkable improvement in terms of achieving higher profit margins, lower cost of fund, asset size and quality, product-diversity, and outreach. This industry is growing at a rapid pace that contribute to the largest proportion of financing (82\%) with the participation of conventional banks' offering Islamic banking products and services (Fitchratings, 2021). The conventional banks are attracted by the higher profitability and growth of Islamic banks.

The relations of bank's profit with economic growth via financial sector development is well-established. Besides, the stock market development has significant impact on capital accumulation, productively and growth of banking sector (King \& Levine, 1993; Levine \& Zervos, 1998). Bank and capital market are much related where one can be developed at the cost of other (Allen \& Gale, 1999). Bank's profitability is affected by its stock value. The bank faces challenging condition once its value of stock falls. On the other hand, bank's profitablity depends on external shocks of oil prices and stock prices (Alaagam, 2019; Hesse \& Poghosyan, 2009). For instance, the fluctuation in oil prices may harm bank's profit directly due to the expansion of oil-based lending for businesses and projects and surplus liquidity. The banking sector of oil exporting country may be adversely affected by the decrease of oil 
Amin | Asymmetric Impact of Oil Prices and Stock Prices on Bank's Profitability: Evidence from Saudi Islamic Banks

prices. This leads to fall of exports, government revenues and fiscal balance, GDP growth and equity prices, which creates negative impact on banks' balance sheets and credit expansion. Besides, increase in oil prices might link to higher domestic demand which restore the higher banking performance by lending to low non-performing loan. In contrast, realizing the mechanism from aggregate supply side, oil price hike is beneficial to the Saudi economy as its product capacity expanded and lead to higher economic growth. This fact is proven by the incident of higher oil prices between 2005 and 2008 where most of the oil-based economies including Saudi Arabia funded long-term investment project for diversifying their domestic economies.

Being a major oil-exporting country in MENA region, Saudi economy and its financial sector including banking industry largely rely on oil prices. According to Saudi General Authority of Statistics, the Saudi economy contracted by 7 percent in the 2020Q2 because of 61.8\% decrease in oil exports, and both government and private sectors experienced a declining growth rates of 10.1 percent and 3.5 percent, respectively (General Autority of Statistics, 2020). On the other hand, Saudi stock market is appearing as one of key players due to its inclusion in the emerging market (Suhad \& Tahar, 2021) and any volatility of this market also affect the banking sector (Alkhareif, 2016) .

Previous studies conducted in Saudi Arabia focused on determinants of banks profitability by emphasizing the internal factors i.e., asset, liability, bank size, leverage ratio etc., while some other studies focus on the efficiency and productivity analysis of both conventional and Islamic banks in Saudi Arabia (M. Hassan, Amin, Khokhar, \& Khan, 2020; M. Hassan, Khan, Amin, \& Khokhar, 2018; Khan et al., 2018; Khokhar, Hassan, Khan, \& Amin, 2020). As far as the existing literature is concerned, no study has conducted that examined the external factors like oil prices and stock prices that affect the Islamic banks' profitability in Saudi Arabia by using non-linear approach. This study is an attempt to fill the gap in the existing literatures.

\subsection{Objective}

This study attempts to examine the non-linear relations of oil prices and stock prices on the profitability of Saudi Islamic banks. The rate of Return on Equity (ROE) and Return of Assets (ROA) are used as the proxies of banks' profitability. This study includes two Islamic banks, such as Bank Alrajhi and Bank Aljazira for the asymmetric analysis. The study objective is achieved by a nonlinear autoregressive distributed lag nonlinear autoregressive distributed lag (NARDL) model (Y. Shin, Yu, \& Greenwood-Nimmo, 2014). This study is an attempt to contribute in the existing literatures by extending the asymmetric analysis with NARDL model. 
Amin | Asymmetric Impact of Oil Prices and Stock Prices on Bank's Profitability: Evidence from Saudi Islamic Banks

Apart from this section, the rest of this paper is structured as follows: section two highlights on relevant past studies in relations to the variables under study, section three focuses on the data and research method, section four concentrates on the result and discussion of the estimated NARDL model and final section makes concluding remarks with policy recommendations.

\section{Literature Review}

This section highlights on the existing literatures on the bank's profitability indicators such as Return on Equity (ROE) and Return on Assets (ROA). Also, the findings past studies that focus on the its relationships among the oil prices, stock prices and GDP. The main purpose of reviewing the extant literature is to make the theoretical foundation for constructing the models.

\subsection{Banks' Profitability}

The existing studies highlighting on bank's profitability is presented by the proxy of two common factors such as Return on Equity (ROE) and Return on Assets (ROA). Some studies measure the bank's profitability with these two indicators and consider as endogenous variables (Anwar \& Herwany, 2006; Arora \& Arora, 2013; T. Beck, Demirgüç-Kunt, \& Levine, 1999; Kosmidou, 2008; Naceur \& Goaied, 2008; E. Sharma \& Mani, 2012; Staikouras \& Wood, 2004; Sufian \& Habibullah, 2010). Both ROE and ROA are the components of bank's income statement which are calculated as the profit after paying the tax.

The return on equity (ROE) indicates bank's management ability and efficiency to utilize the funds of shareholders and it plays a key role in destemming the degree of financial leverage of the institution (Hassan \& Bashir, 2003). On the other hand, ROA indicates the profit gained per value of assets which also shows the managerial capacity to gain profits by utilizing banks' investment and financial (Hassan \& Bashir, 2003). It also describes the bank's ability to gain returns from diversified assets' portfolio (Rivard \& Thomas, 1997; Rosly \& Bakar, 2003). Since ROE is influenced by ROA and the latter might be lower, the banks usually apply financial leveraging principles to enhance ROE for achieving the competitive advantages (Hassan \& Bashir, 2003).

\subsection{Determinants of Banks' Profitability}

Empirical studies that measure the bank profitability are categorized into two factors i.e., internal and external. This study focuses on the oil prices, stock prices and GDP as the external factors of Islamic bank's probability. These are the factors that are not controlled by the bank's management; however, they have positive effect on the bank's profitability. Following sub-section reviews related literatures on these external factors of bank's profitability. 
Amin | Asymmetric Impact of Oil Prices and Stock Prices on Bank's Profitability: Evidence from Saudi Islamic Banks

\subsubsection{Oil Prices and Banks' Profitability}

The oil-exporters depend on oil export which also creates a positive link with the profitability of their banking industries. Despite the fact, many studies ignore this factor in determining the bank's profitability (Demirgüç-Kunt \& Huizinga, 1999; Hassan \& Bashir, 2003). Only few studies focus on oil price as an external factor of bank's profitability. Hesse and Poghosyan (2009) highlight on MENA region by dividing the banks into three types: Islamic, conventional, and investment banks. Zantioti (2009) and Kpodar and Imam (2010) concentrate on Islamic banks' profitability and observe that oil prices have positive and significant impact as it improves the banks' financial condition with higher outreach in the case of net oil exporters in MENA region. Conversely, the net oil importing countries in the same region experience positive effect of GDP on bank's profitability. This happens because of the increasing flow of deposits and economic activities. Besides, Hesse and Poghosyan (2009) evaluate the indirect impact of oil shocks on the Islamic, conventional and investment banks' profitability in MENA region. This study also focuses other institutional and macroeconomic variables. Essayyad and Madani (2003) conduct a similar study and observe a positive link between bank's profitability and oil prices in Saudi Arabia. Kpodar and Imam (2010) also experience the similar findings.

\subsubsection{Stock Market and Banks' Profitability}

The outcome of existing literatures focusing on the stock market and bank's profitability are mixed. The positive linkage is expected between the development of stock market and bank's performance because a welldeveloped stock market ensures the easy flow of information to banking institutions enabling them to evaluate the potential risk of investment. Besides, a sound stock market creates confidence among the borrower to obtain credit from the bank which also lead to increase the banks' profit. On the contrary, the stock market can also affect negatively on the bank's profitability. This might be the case of a competitive market where stock market appears to substitute to the banking sector.

Eichengreen and Gibson (2001) examine the determinants of Greek commercial banks' profitability and observe that two factors i.e. market share and concentration ratios of Greek banks have positive relation with banks' profitability. Kaya (2002) find a positive link of market share with banks' profitability in term of ROE. Hassan and Bashir (2003) identify a positive and significant role stock market development and banks' profitability. In contrary to these findings, Rossi, Borroni, Lippi, and Piva (2018) observe that stock market has negative relation with banks' ROA and ROE. 
Amin $\mid$ Asymmetric Impact of Oil Prices and Stock Prices on Bank's Profitability: Evidence from Saudi Islamic Banks

\subsubsection{Real GDP Growth and Banks' Profitability}

Many studies focus on macroeconomic and financial determinants of bank's profitability. These are GDP growth, interest rates, inflation, stock market instability (U. Albertazzi \& L. Gambacorta, 2009; Athanasoglou, Brissimis, \& Delis, 2008; Beckmann, 2007; Lee \& Hsieh, 2013). The existing literatures also reveal the mixed results. Some studies find no influence (P. Sharma, Gounder, \& Xiang, 2013) while others explore negative impact on banks' profitability (Ben Ameur \& Mhiri, 2013; Ben Naceur \& Omran, 2011; Sufian, 2009; Tan \& Floros, 2012; Yanikkaya, Gumus, \& Pabuccu, 2018). On the contrary, some other studies observe that economic growth enhance bank's profitability. This is due to the economic boom and increasing demand for banking products and services (U. Albertazzi \& L. Gambacorta, 2009; Athanasoglou et al., 2008; Davydenko, 2011; Dietrich \& Wanzenried, 2014a; Flamini, McDonald, \& Schumacher, 2009; Zeitun, 2012). With this mixed result, this study is an attempt to examine the positive relation of bank's profit and GDP growth in Saudi Arabia.

\section{Methodology}

\subsection{Data}

The study focuses on annual data (2000-2020) of two largest full-fledged Islamic banks in Saudi Arabia i.e., Bank Alrajhi and Bank Aljazira. Only two Islamic banks are selected due to their early Islamic banking operation in Saudi Arabia whereas other two banks such as, Bank Albilad and Bank Alinma started their Islamic banking in 2004 and 2006, respectively. It considers two profitability indicators of banks i.e., Return of Equity (ROE) and Return of Assets (ROA) as the endogenous variables whereas stock prices of Alrajhi and Aljazira, oil prices and real Gross Domestic Product are considered as the exogenous variables. All the data are extracted from Bloomberg database.

\subsection{Model Specification}

Table 1 shows the description of the variables with the measurement unit and formula of extracting the dependent variables. 
Amin | Asymmetric Impact of Oil Prices and Stock Prices on Bank's Profitability: Evidence from Saudi Islamic Banks

Table 1. Definition of variables

\begin{tabular}{|c|c|c|}
\hline Levelling & Description & Measurement \\
\hline \multirow{2}{*}{ ROE } & \multirow{2}{*}{$\begin{array}{l}\text { Return of Equity is the ratio of net profit to } \\
\text { shareholders' equity }\end{array}$} & Net Profit \\
\hline & & $\overline{\text { Total Equity }}$ \\
\hline \multirow{2}{*}{ ROA } & \multirow{2}{*}{$\begin{array}{l}\text { Return of Asset is the ratio of bank net } \\
\text { profit to total assets }\end{array}$} & Net Profit \\
\hline & & $=\overline{\text { Total Assets }}$ \\
\hline STOCKP & Stock prices (USD) & Converted to natural logarithm. \\
\hline OILP & Brent Oil price (USD) & $\begin{array}{l}\text { Converted to natural logarithm. } \\
\text { Real GDP is calculated from GDP }\end{array}$ \\
\hline RGDP & Real Gross Domestic Product (USD) & $\begin{array}{l}\text { Deflator and converted to natural } \\
\text { logarithm. }\end{array}$ \\
\hline
\end{tabular}

Source: Bloomberg (2021)

This study adopts a nonlinear autoregressive distribution lag (NARDL) approach to show the long-run and short-run asymmetric relations of ROE and ROA with STOCKP, OILP and RGDP are constructed based on the approaches of by Shin, Yu, \& Greenwood-Nimmo (2014) and Shin and Smith (2001):

$\mathrm{ROE}_{t}=\theta_{0}+\theta_{1} \mathrm{STOCKP}_{t}^{+}+\theta_{2} \mathrm{STOCKP}_{t}^{-}+\theta_{3} \mathrm{OILP}_{t}^{+}+\theta_{4} \mathrm{OILP}_{t}^{-}+\theta_{5} \mathrm{RGDP}_{t}+e_{t}$

$\mathrm{ROA}_{t}=\theta_{0}+\theta_{1} \mathrm{STOCKP}_{t}^{+}+\theta_{2} \mathrm{STOCKP}_{t}^{-}+\theta_{3} \mathrm{OILP}_{t}^{+}+\theta_{4} \mathrm{OILP}_{t}^{-}+\theta_{5} \mathrm{RGDP}_{t}+e_{t}$

where $\theta=\left(\theta_{0}, \theta_{1}, \theta_{2}, \theta_{3}, \theta_{4}, \theta_{5}\right.$, and $\left.\theta_{6}\right)$ indicates the cointegrating vector of long-run coefficients; and $e_{t}$ is the error term which is assumed to follow normal and independent distribution with zero mean value and constant variance.

$$
\begin{aligned}
& \operatorname{STOCKP}_{t}^{+}=\sum_{i=1}^{t} \Delta \mathrm{STOCKP}_{i}^{+}=\sum_{i=1}^{t} \max \left(\Delta \mathrm{STOCKP}_{\mathrm{i}}, 0\right) \\
& \operatorname{STOCKP}_{t}^{-}=\sum_{i=1}^{t} \Delta \mathrm{STOCKP}_{i}^{-}=\sum_{i=1}^{t} \max \left(\Delta \operatorname{STOCKP}_{\mathrm{i}}, 0\right) \\
& \operatorname{OILP}_{t}^{+}=\sum_{i=1}^{t} \Delta \operatorname{OILP}_{i}^{+}=\sum_{i=1}^{t} \max \left(\Delta \operatorname{OILP}_{\mathrm{i}}, 0\right) \\
& \operatorname{OILP}_{t}^{-}=\sum_{i=1}^{t} \Delta \operatorname{OILP}_{i}^{-}=\sum_{i=1}^{t} \max \left(\Delta \operatorname{OILP}_{\mathrm{i}}, 0\right)
\end{aligned}
$$

The long-run relationship of ROE and ROA with STOCKP and OILP increase are $\theta_{1}$ and $\theta_{3}$, and decrease are $\theta_{2}$, and $\theta_{4}$ which are assumed to be positive and negative, respectively. Since $\theta_{2}$ and $\theta_{4}$ are predicted to be positive which are supposed to change in identical direction, for example, any increase in STOCKP impact positive long-run changes in ROE and ROA as related to the effect of STOCKP decrease on ROE and ROA of an identical extent i.e., $\theta_{1}>$ $\theta_{2}$. Hence, the long-run relationship as shown in Eq.1 and Eq.2 indicate the non-linear and long-run STOCKP change pass-through to the ROE and ROA.

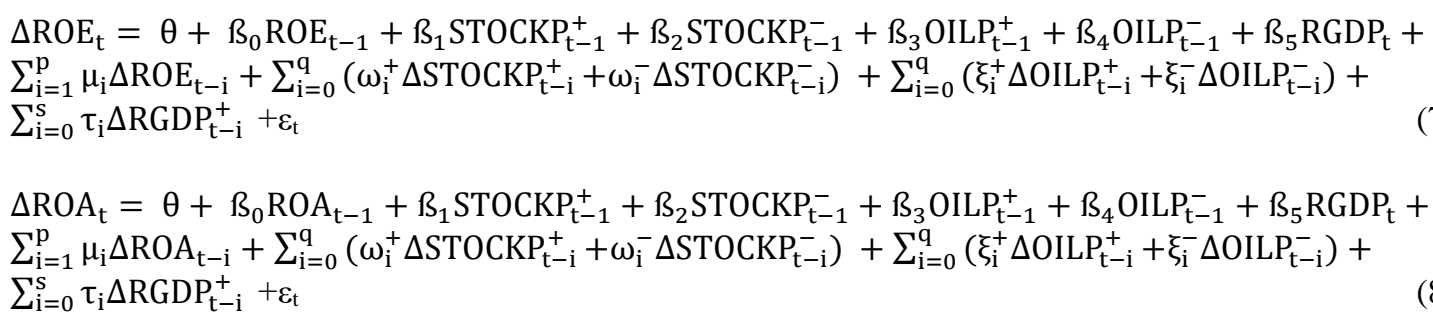


Amin Asymmetric Impact of Oil Prices and Stock Prices on Bank's Profitability: Evidence from Saudi Islamic Banks

Two of the exogenous variables are shown in asymmetric form while RGDP is presented as liner form; $p, q$ and $s$ indicate the lag orders. The long-run parameters $\left(\theta_{1}=-\beta_{1} / \beta_{0}\right),\left(\theta_{2}=-\beta_{2} / \beta_{0}\right),\left(\theta_{3}=-\beta_{3} / \beta_{0}\right)$, and $\left(\theta_{4}=-\beta_{4} / \beta_{0}\right)$ show the long-run effect of STOCKP and OILP (exogenous variables) increases and decreases, respectively, on ROE and ROA (endogenous variables). Besides, $\sum_{i=0}^{q} \omega_{\mathrm{i}}^{+}$and $\sum_{i=0}^{q} \omega_{\mathrm{i}}^{-}$and $\sum_{i=0}^{q} \xi_{\mathrm{i}}^{+}$indicate the short-run effect of STOCKP and OILP increases and decreases on ROE and ROA, respectively. Thus, Eq.7 and Eq. 8 present the asymmetric long-run and short-run effect of STOCKP and OILP on ROE and ROA.

\subsection{Method}

As mentioned outset that this study applies NARDL approach which is developed by Y. Shin et al. (2014). While many studies use ARDL approach introduced by M Hashem Pesaran, Shin, and Smith (1999) and later on developed by M.H. Pesaran, Shin, and Smith (2001), this study focuses on NARDL approach to examine the non-linear relationships among the variables. Following stages are maintained in estimating NARDL model: i) unit root test for detecting the absence of I (2) and presence of I (0) or I (1) or both; ZA tests to detect the structural breaks, ii) general-to-specific principles similar to OLS technique on Eq.7 and Eq. 8 to construct final NARDL model via trimming the insignificant lags, iii) NARDL bound test method to identify the cointegrating variables (Y Shin, Yu, \& Greenwood-Nimmo, 2011) with the null hypothesis (no cointegration) ( $\left.H_{n}: \beta_{0}=\beta_{1}{ }^{+}=\beta_{2}{ }^{-}=\beta_{3}{ }^{+}=\beta_{4}{ }^{-}=\beta_{5}=0\right)$ is inspected against the alternative hypothesis (presence of cointegration) $\left(H_{a}: \beta_{0} \neq \beta_{1}{ }^{+} \neq \beta_{2}{ }^{-} \neq \beta_{3}{ }^{+} \neq \beta_{4}{ }^{-} \neq\right.$ $\left.\beta_{5} \neq 0\right)$, iv) long-run and short-run asymmetric relations between the endogenous and exogenous variables by applying Wald test, v) non-linear cumulative dynamic multiplier (CDM) effects by the following equations:

$$
\begin{aligned}
& m_{k}^{+}=\sum_{j=0}^{k} \frac{\delta R O E_{t+i}}{\delta S T O C K P_{t-1}^{+}}, m_{k}^{-}=\sum_{j=0}^{k} \frac{\delta R O E_{t+i}}{\delta S T O C K P_{t-1}^{-1}}, \mathrm{k}=0,1,2,3, \ldots \text { (9) } \\
& m_{k}^{+}=\sum_{j=0}^{k} \frac{\delta R O A_{t+i}}{\delta S T O C P_{t-1}^{+}}, m_{k}^{-}=\sum_{j=0}^{k} \frac{\delta R O A_{t+i}}{\delta S T O C K P_{t-1}^{-}}, \mathrm{k}=0,1,2,3, \ldots(10) \\
& m_{k}^{+}=\sum_{j=0}^{k} \frac{\delta R O E_{t+i}}{\delta O I L P_{t-1}^{+}}, m_{k}^{-}=\sum_{j=0}^{k} \frac{\delta R O E_{t+i}}{\delta O I L P_{t-1}^{-}}, \mathrm{k}=0,1,2,3, \ldots(11) \\
& m_{k}^{+}=\sum_{j=0}^{k} \frac{\delta R O A_{t+i}}{\delta O I L P_{t-1}^{+}}, m_{k}^{-}=\sum_{j=0}^{k} \frac{\delta R O A_{t+i}}{\delta O I L P_{t-1}^{-}}, \mathrm{k}=0,1,2,3, \ldots(12)
\end{aligned}
$$

Note that, $\mathrm{k} \rightarrow \infty, m_{k}^{+} \rightarrow \theta_{1}$, and $\theta_{3}$ and $m_{k}^{-} \rightarrow \theta_{2}$ and $\theta_{4}$. 
Amin | Asymmetric Impact of Oil Prices and Stock Prices on Bank's Profitability: Evidence from Saudi Islamic Banks

\section{Results and Analysis}

\subsection{Descriptive Statistics}

Table 2 displays the descriptive statistics of variables under this study where it indicates that ROE is less volatile than ROA while oil price is less volatile than stock prices. The real GDP of Saudi Arabia appears to be fourth least volatile variable where stock prices are highest volatile variable throughout the study period between 2000-2020.

Table 2. Descriptive Statistics

\begin{tabular}{lrcrcc}
\hline \multicolumn{1}{c}{ Variable } & \multicolumn{1}{c}{ Mean } & Median & Maximum & Minimum & Std. Dev. \\
\hline ROA $_{R}$ & 3.247640 & 3.070900 & 7.292900 & 0.198114 & 1.855891 \\
ROE $_{R}$ & 0.229315 & 0.220321 & 0.418235 & 0.152878 & 0.075460 \\
ROA $_{J}$ & 0.11995 & 0.092962 & 0.470678 & 0.006136 & 0.103784 \\
ROE $_{J}$ & 0.022664 & 0.022448 & 0.032926 & 0.015099 & 0.004794 \\
STOCKP & 64.60654 & 64.15582 & 150.1119 & 17.00530 & 31.23058 \\
OILP & 55.65333 & 48.29000 & 92.40000 & 31.23000 & 20.03583 \\
RGDP & 14.51190 & 14.49900 & 14.76630 & 14.12686 & 0.225578 \\
\hline \multicolumn{7}{c}{ Source: Bloomberg (2021) }
\end{tabular}

\subsection{Stationary and Structural Break Test}

Table 3 displays the result of both Dickey-Fuller (ADF) and Phillips-Perron (PP) test (Dickey \& Fuller, 1979; Perron, 1989) with the integration order of variables under study which indicate that all the five variables have mixed order of I (0) and I(1) and most importantly none of the single variable is falling under integration order of $\mathrm{I}(0)$. Afterwards, this study conducts the ZivotAndrews (ZA) test (Zivot \& Andrews, 1992) to identify the possible structural break point. In table 3, two structural break points have been identified. Based on these result, two dummy variables (2008 and 2014) are created which are included in the NARDL model as exogenous variables. The justifications of considering two dummies in 2008 and 2014 are for controlling the external shocks of global financial crisis of 2008 and fall of world oil prices on the Islamic banking profitability (ROE and ROA) in Saudi Arabia. Some studies find that the financial crisis of 2008 have negative impact on the banks' performances (Gulati \& Kumar, 2016; Tzeremes, 2015). 
Amin | Asymmetric Impact of Oil Prices and Stock Prices on Bank's Profitability: Evidence from Saudi Islamic Banks

Table 3. Unit Root With Structural Break Test Results

\begin{tabular}{|c|c|c|c|c|c|c|}
\hline & \multicolumn{2}{|c|}{ ADF } & \multicolumn{2}{|c|}{ PP-Test } & \multicolumn{2}{|c|}{ Zivot Andrews } \\
\hline & $\mathrm{I}(0)$ & I(1) & $I(0)$ & I(1) & t-stat & $\begin{array}{l}\text { Break } \\
\text { Point }\end{array}$ \\
\hline$\overline{\mathrm{ROA}_{R}}$ & $-1.29[1]$ & $-3.04 * * *[0]$ & $-2.50[1]$ & $-3.02 * *[4]$ & $-2.12 * * *[1]$ & 2008 \\
\hline $\mathrm{ROE}_{\mathrm{R}}$ & $-5.02 * * *[1]$ & $-2.13 * * *[0]$ & $-3.92 * *[0]$ & $-4.15 * * *[2]$ & $-4.44 *[2]$ & 2008 \\
\hline $\mathrm{ROA}_{\mathrm{J}}$ & $-1.12[1]$ & $-2.24 * * *[0]$ & $-1.70[1]$ & $-3.08 * *[4]$ & $-3.11 * * *[1]$ & 2008 \\
\hline $\mathrm{ROE}_{\jmath}$ & $-4.02 * * *[1]$ & $-2.16 * * *[0]$ & $-2.99 * * *[0]$ & $-3.90 * * *[2]$ & $-4.14 * *[2]$ & 2008 \\
\hline STOCKP & $-3.62[0]$ & $-3.71 * * *[0]$ & $-1.75[1]$ & $-3.55^{* * *[1]}$ & $-3.54 * * *[1]$ & 2014 \\
\hline OILP & $-2.22[1]$ & $-3.98 * * *[1]$ & $-2.53[5]$ & $-6.86 * * *[16]$ & $-3.50^{* *}$ & 2014 \\
\hline LRGDP & $-3.78[1]^{* *}$ & $-4.74 * *[0]$ & $-4.18[1]^{* *}$ & $-4.63 * *[5]$ & $-4.21 * * *[1]$ & 2008 \\
\hline
\end{tabular}

Note: An intercept and trend option is used for ADF followed by the null hypothesis: the series contain a unit root. In the case of ADF test, numbers in [ ] indicate optimal lags and for PP test, number in [ ] is Bandwidth: (Newey-West automatic) using Bartlett kernel. SC is applied for selecting the optimal lag order. The subscript $\mathrm{R}$ and $\mathrm{J}$ stand for Alrajhi and Aljazira, respectively.

Superscript $*, * *$, and $* * *$ indicate the rejection of the null hypothesis at $10 \%, 5 \%$, and $1 \%$, respectively.

\subsection{Brock, Dechert and Scheinkmakn (BDS) Test}

Apart from the stationary and the structural break test results, this study also conducts Brock, Dechert and Scheinkmakn (BDS) test for detecting the nonlinear dependencies of both endogenous and exogenous variables as recommended by Broock, Scheinkman, Dechert, and LeBaron (1996). The results in table 4 suggest rejecting the null hypothesis of the error terms which are assumed to follow independent and identical distribution of across various dimensions. The rejection of null hypothesis indicates the existence of nonlinearity among the variables and hence justifies to estimate NARDL model.

Table 4. BDS Non-Linearity Test Results

\begin{tabular}{llllll}
\hline & \multicolumn{5}{c}{ Embedding Dimension=m } \\
\cline { 2 - 6 } Series & \multicolumn{1}{c}{$\mathrm{m}=2$} & \multicolumn{1}{c}{$\mathrm{m}=3$} & \multicolumn{1}{c}{$\mathrm{m}=4$} & \multicolumn{1}{c}{$\mathrm{m}=5$} & \multicolumn{1}{c}{$\mathrm{m}=6$} \\
\hline ROA $_{\mathrm{R}}$ & $0.080083^{* * *}$ & $0.091148^{* * *}$ & $0.040173^{*}$ & $0.073897^{* *}$ & $0.087153^{* * *}$ \\
ROE $_{\mathrm{R}}$ & $0.11^{* * *}$ & $0.15421^{* * *}$ & $0.19445^{* * *}$ & $0.209906^{* * *}$ & $0.232351^{* * *}$ \\
ROA $_{\mathrm{J}}$ & $0.072465^{* * *}$ & $0.106602^{* * *}$ & $0.119336^{* *}$ & $0.096786^{*}$ & $0.0606^{*}$ \\
ROE $_{\mathrm{J}}$ & $0.057368^{* * *}$ & $0.072339^{* * *}$ & $0.083339^{* * *}$ & $0.084906^{* * *}$ & $0.098842^{* * *}$ \\
STOCKP & $0.061468^{* * *}$ & $0.124135^{* * *}$ & $0.1656^{* * *}$ & $0.196757^{* * *}$ & $0.218591^{* * *}$ \\
OILP & $0.09831^{* * *}$ & $0.157826^{* * *}$ & $0.190061^{* * *}$ & $0.185654^{* * *}$ & $0.157062^{* * *}$ \\
RGDP & $0.189889^{* * *}$ & $0.314598^{* * *}$ & $0.404203^{* * *}$ & $0.460978^{* * *}$ & $0.487706^{* * *}$ \\
\hline Note & The subscript R and J stand for Alrajhi Bank and Aljazira Bank, respectively Superscript*
\end{tabular}

$* *$, and $* * *$ indicate the rejection of null hypothesis at $10 \%, 5 \%$, and $1 \%$, respectively. 
Amin $\mid$ Asymmetric Impact of Oil Prices and Stock Prices on Bank's Profitability: Evidence from Saudi Islamic Banks

\subsection{Selection of Optimal Lag Order}

One of the requirements prior to estimating NARDL model is to select an appropriate lag orders of endogenous and exogenous variables. The Schwarz Criteria (SC) lag length criteria has been chosen for the estimation of final NARDL model. Figures 1-4 depict four set of appropriate NARDL models which are derived from top twenty models from each set.

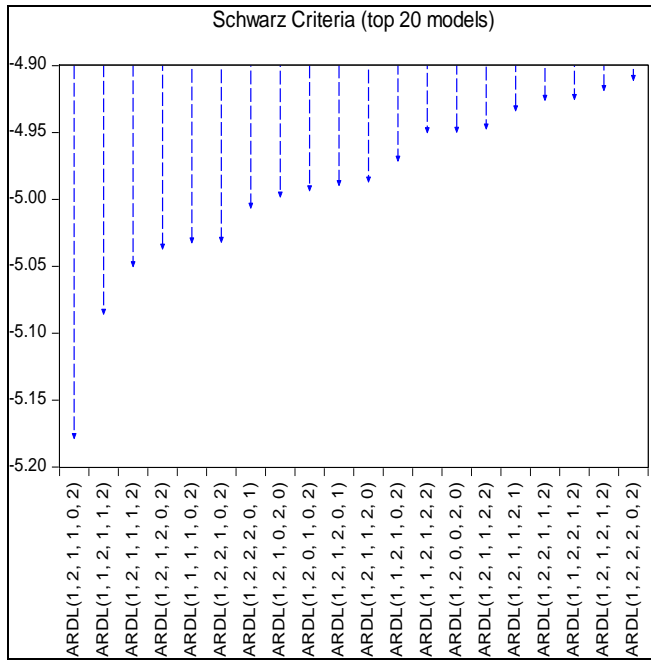

Figure 1. ROE $E_{R}$ RGDP OILP, STOCKP

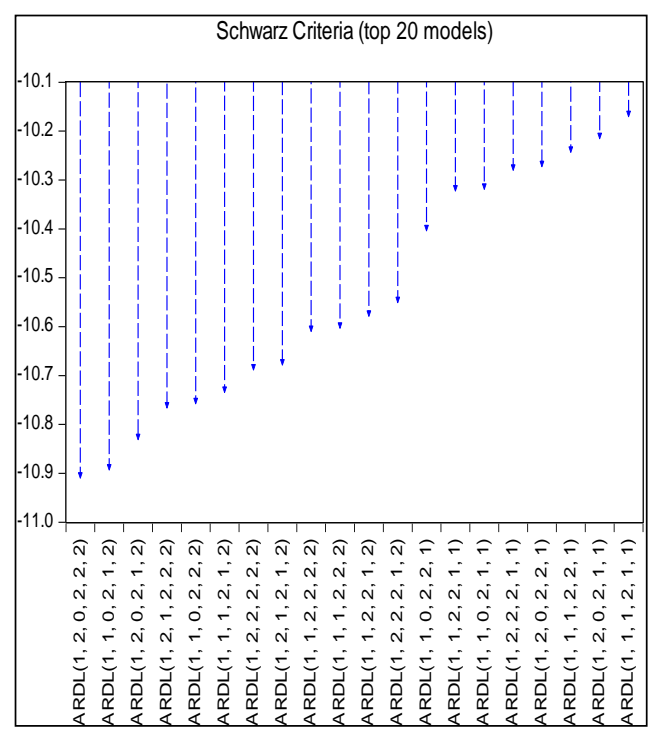

Figure 3. ROEJ, RGDP OILP, STOCKP

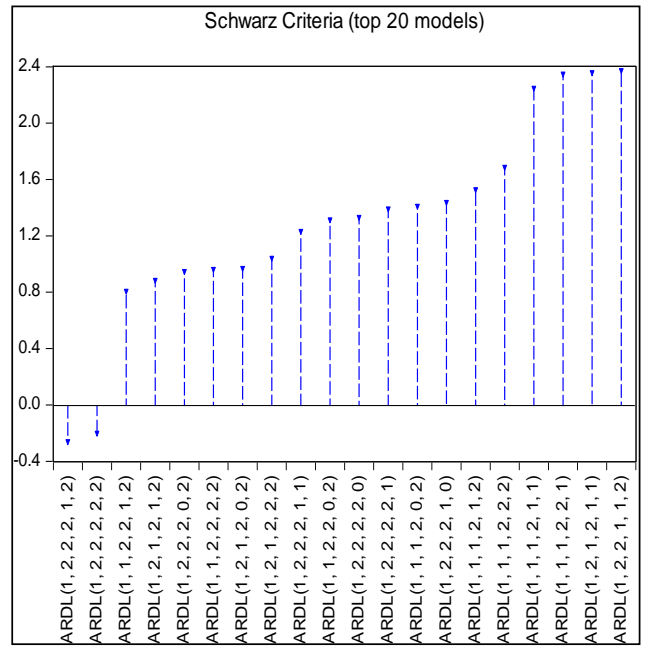

Figure 2. ROAR, RGDP OILP, STOCKP

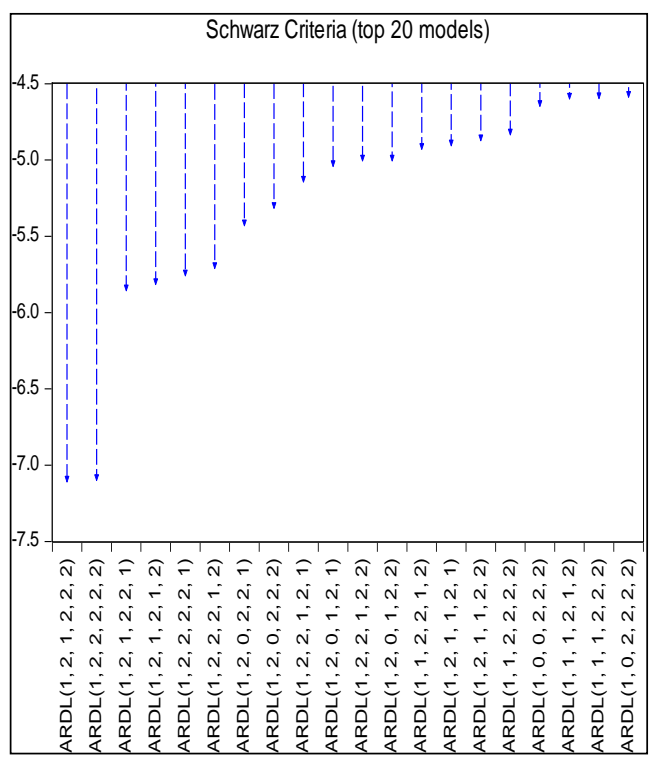

Figure 4. ROA, RGDP OILP, STOCKP 
Amin | Asymmetric Impact of Oil Prices and Stock Prices on Bank's Profitability: Evidence from Saudi Islamic Banks

\subsection{Bound Test for Cointegration}

In this study, a baseline model is constructed for identifying cointegrating relations among endogenous and exogenous variables where two tests are applied i.e., F-test, and T-test. The general principle is that if the estimated value of F-statistics and T-statistics are greater than their respective critical values (upper limit), null hypothesis of no cointegration is rejected. The results of table 5 show the evidence of rejection of null hypothesis at $1 \%$ significant level, thus confirming that in the long run variables move together.

Table 5. NARDL Bound testing for cointegration

\begin{tabular}{|c|c|c|}
\hline \multirow[t]{2}{*}{ Model } & Long-run relationship & \multirow[t]{2}{*}{ Decision } \\
\hline & $F_{p s s}$ & \\
\hline $\mathrm{ROE}_{R}, \mathrm{RGDP}$ OILP, STOCKP-4.86*** & $15.78 * * *$ & Cointegration \\
\hline ROA $A_{R}, R G D P$ OILP, STOCKP-4.10** & $47.55^{* * * *}$ & Cointegration \\
\hline ROE & $16.13 * * *$ & Cointegration \\
\hline $\mathrm{ROA}_{\mathrm{J}}, \mathrm{RGDP}$ OILP, STOCKP $-6.25^{* * *}$ & $23.35^{* * *}$ & Cointegration \\
\hline
\end{tabular}

Significance level

\begin{tabular}{cccc}
\multicolumn{2}{c}{ t-statistics } & \multicolumn{2}{c}{ F-statistics } \\
\hline Lower & Upper & Lower & Upper \\
bound & bound & bound & bound \\
\hline-3.43 & -4.79 & 4.53 & 6.37 \\
-2.86 & -4.19 & 3.13 & 4.61 \\
-2.57 & -3.86 & 2.58 & 3.86
\end{tabular}

Note: Number of parameters $(K)$ appear in original model $K=5$, Critical Value for Finite sample, $N=30$; The subscript $\mathrm{R}$ and $\mathrm{J}$ stand for Alrajhi and Aljazira, respectively. Superscript $*, * *$, and ${ }^{* * *}$ indicate the rejection of null hypothesis at $10 \%, 5 \%$, and $1 \%$, respectively.

\subsection{Results of NARDL Estimation}

\subsubsection{Short-run Relation}

Table 6 displays the NARDL estimated results for two models i.e., $\mathrm{ROE}_{R}$ and


significant impact on ROE $\mathrm{R}$ where the positive shocks dominate over the negative one, suggesting that a $1 \%$ increase in OILP will increase the ROE ${ }_{R}$ by $0.002 \%$ whereas $1 \%$ decrease in OILP will increase the ROE ${ }_{R}$ by $0.001 \%$. This finding is similar to Zantioti (2009) that focuses on net oil exporting countries in MENA region. Again, in the short-run for $\mathrm{ROE}_{\mathrm{J}}$, positive shocks of OILP has no impact on ROEJ, but negative shock of OILP has significant impact on ROEJ, implying that $1 \%$ decrease in OILP will increase the ROEJ by $0.001 \%$. The reason might be the case of increasing net profit of banks and decreasing the value of total equity. It also indicates that bank's expansion of oil-based lending and issue of surplus liquidity. 
Amin $\mid$ Asymmetric Impact of Oil Prices and Stock Prices on Bank's Profitability: Evidence from Saudi Islamic Banks

Table 6. Estimated Results of NARDL Models Based on ROE

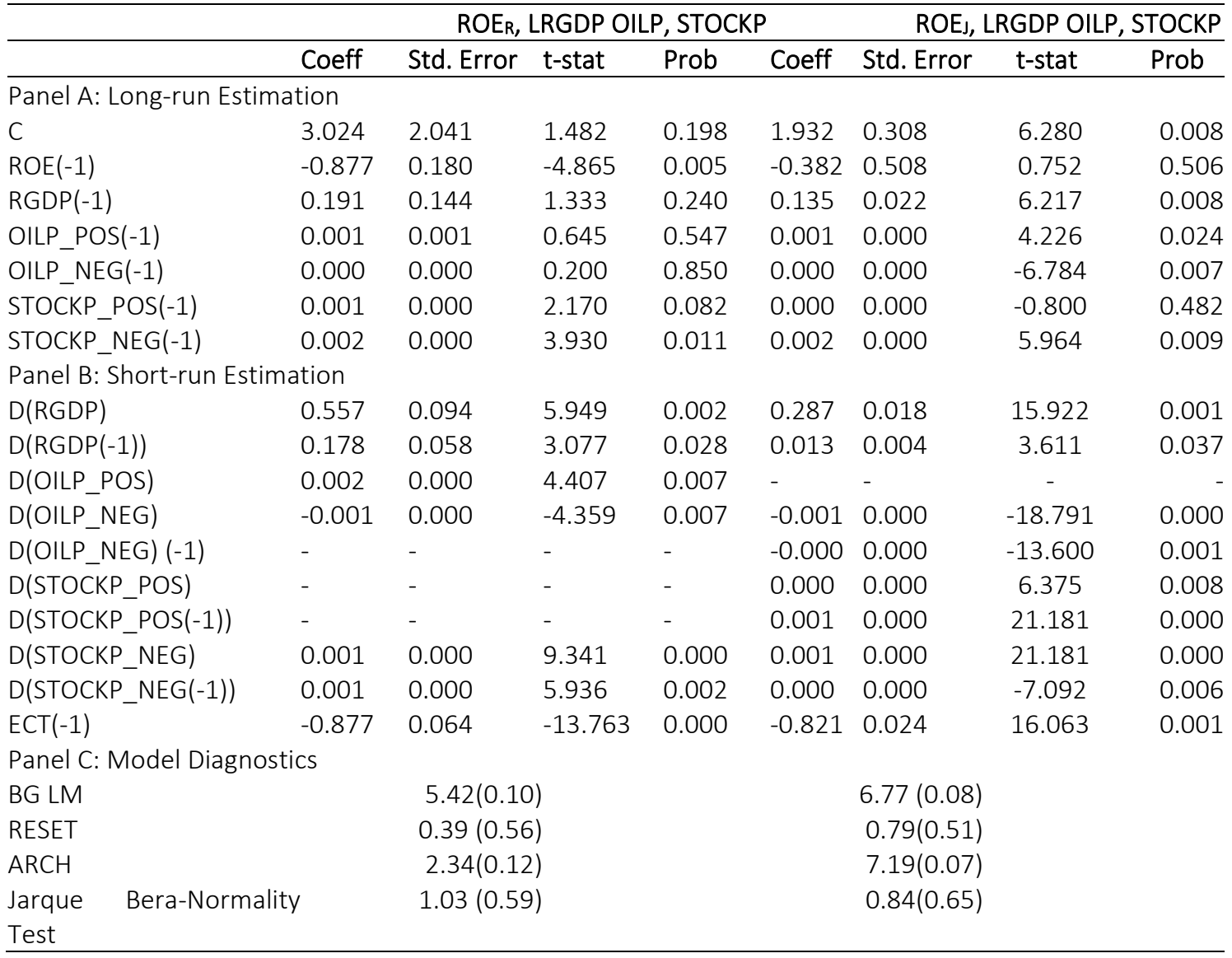

Note: Two dummy variables are excluded in the final NARDL model because of their insignificant values. The subscript $\mathrm{R}$ and $\mathrm{J}$ stand for Alrajhi and Aljazira, respectively. Superscript *,**, and *** indicate the rejection of null hypothesis at $10 \%, 5 \%$, and $1 \%$, respectively

Interestingly, positive shocks of STOCKP has no impact on ROE , but negative shock of STOCKP has significant impact on ROE $R_{\text {. I }}$ It indicates that $1 \%$ decrease in STOCKP will decrease the $R_{R}$ by $0.001 \%$. Both positive and negative shocks in STOCKP have significant impact on $\mathrm{ROE}_{\text {, }}$, indicating that, a $1 \%$ increase in STOCKP will increase the ROE, by $0.001 \%$ whereas $1 \%$ decrease in STOCKP will decrease the ROE, by $0.001 \%$. These outcomes are consistent with Eichengreen and Gibson (2001), Hassan and Bashir (2003) and Kaya (2002).

The RGDP has significant impact on $\mathrm{ROE}_{\mathrm{R}}$ and $\mathrm{ROE}_{\mathrm{J}}$, where the magnitude of the impact is observed higher $(0.55 \%)$ in case of $R^{2} E_{R}$ than $(0.29 \%)$ for the ROEJ. These results are in line with the studies Dietrich and Wanzenried (2014b), Zeitun (2012), Muhamad, Amir, and Abdelhakim (2013). The coefficient of the error correction term (ECT) of $\mathrm{ROE}_{\mathrm{R}}$ and $\mathrm{ROE}$, are is $-88 \%$ and $-82 \%$ indicating that market disequilibrium is adjusted at a speed of $88 \%$ and $82 \%$ per period, respectively. In other words, the mark equilibrium can be achieved with around one year. 
Amin $\mid$ Asymmetric Impact of Oil Prices and Stock Prices on Bank's Profitability: Evidence from Saudi Islamic Banks

Table 7. Estimated Results of NARDL Models Based on ROA

\begin{tabular}{|c|c|c|c|c|c|c|c|c|}
\hline & \multicolumn{4}{|c|}{ ROA $_{R}$, LRGDP OILP, STOCKP } & \multicolumn{4}{|c|}{ ROA, LRGDP OILP, STOCKP } \\
\hline & Coeff & Std. Error t & t-stat & Prob & Coeff $S$ & Std. Error t & \multirow[t]{2}{*}{ t-stat } & \multirow[t]{2}{*}{ Prob } \\
\hline \multicolumn{7}{|c|}{ Panel A: Long-run Estimation } & & \\
\hline C & 3352.483 & 1433.714 & 2.338 & 0.144 & 26.649 & 2.617 & 10.182 & 0.010 \\
\hline $\operatorname{ROE}(-1)$ & 0.429 & 0.695 & 0.617 & 0.600 & -0.743 & 0.119 & -6.251 & 0.025 \\
\hline $\operatorname{RGDP}(-1)$ & 6.249 & 101.250 & -2.333 & 0.145 & 1.869 & 0.182 & -10.245 & 0.009 \\
\hline OILP_POS(-1) & 1.546 & 0.591 & 2.617 & 0.020 & 0.015 & 0.002 & 7.152 & 0.019 \\
\hline OILP_NEG(-1) & -0.370 & 0.181 & -2.041 & 0.051 & -0.005 & 0.000 & -14.357 & 0.005 \\
\hline STOCKP_POS(-1) & 0.116 & 0.039 & -2.945 & 0.099 & 0.003 & 0.001 & 2.711 & 0.113 \\
\hline STOCKP_NEG(-1) & -0.135 & 0.025 & 5.489 & 0.032 & -0.025 & 0.005 & 5.301 & 0.034 \\
\hline \multicolumn{9}{|c|}{ Panel B: Short-run Estimation } \\
\hline $\mathrm{D}(\mathrm{RGDP})$ & 2.750 & 4.993 & 30.596 & 0.001 & 1.868 & 0.045 & 41.102 & 0.001 \\
\hline $\mathrm{D}(\mathrm{RGDP}(-1))$ & 3.846 & 3.089 & 33.613 & 0.001 & 0.469 & 0.026 & 18.318 & 0.003 \\
\hline D(OILP_POS) & 0.925 & 0.029 & 31.516 & 0.001 & 0.013 & 0.000 & 55.855 & 0.000 \\
\hline $\mathrm{D}\left(\mathrm{OILP} \_\mathrm{POS}(-1)\right)$ & 0.893 & 0.027 & 33.352 & 0.001 & - & - & - & . \\
\hline D(OILP_NEG) & -0.303 & 0.009 & -32.136 & 0.001 & -0.006 & 0.000 & -62.052 & 0.000 \\
\hline $\mathrm{D}(\mathrm{OILP}$ _NEG(-1)) & -0.181 & 0.006 & -27.982 & 0.001 & -0.003 & 0.000 & -26.537 & 0.001 \\
\hline D(STOCKP_POS) & 0.164 & 0.005 & 34.384 & 0.001 & 0.004 & 0.000 & 29.633 & 0.001 \\
\hline D(STOCKP_POS (-1)) & - & - & - & - & 0.003 & 0.000 & 19.824 & 0.003 \\
\hline D(STOCKP_NEG) & -0.363 & 0.011 & -31.785 & 0.001 & 0.004 & 0.000 & 21.029 & 0.002 \\
\hline D(STOCKP_NEG(-1)) & -0.323 & 0.011 & -29.836 & 0.001 & -0.005 & 0.000 & -13.164 & 0.006 \\
\hline $\mathrm{ECT}(-1)$ & 0.429 & 0.014 & 31.599 & 0.001 & -0.743 & 0.015 & -50.895 & 0.000 \\
\hline \multicolumn{9}{|c|}{ Panel C: Model Diagnostics } \\
\hline BG LM & & $7.05(0.25)$ & & & & $8.29(0.21)$ & & \\
\hline RESET & & $5.53(0.09)$ & & & & $0.13(0.91)$ & & \\
\hline $\mathrm{ARCH}$ & & $0.18(0.67)$ & & & & $0.29(0.54)$ & & \\
\hline $\begin{array}{l}\text { Jarque Bera-Normality } \\
\text { Test }\end{array}$ & & $2.15(0.34)$ & & & & $1.35(0.51)$ & & \\
\hline
\end{tabular}

Note: Two dummy variables are excluded in the final NARDL model because of their insignificant values. The subscript $\mathrm{R}$ and J stand for Alrajhi and Aljazira, respectively. Superscript $*, * *$, and *** indicate the rejection of null hypothesis at $10 \%, 5 \%$, and $1 \%$, respectively

Table 7 shows the short-run relations of $R O A_{R}$ and $R O A_{\text {s }}$ with exogenous variables. In the short-run $\left(R O A_{R}\right)$, the positive and negative shocks of OILP have significant influence on $\mathrm{ROA}_{R}$, implying that a $1 \%$ increase in OILP will increase the ROA ${ }_{R}$ by $0.92 \%$ whereas $1 \%$ decrease in OILP will increase the $\mathrm{ROA}_{\mathrm{R}}$ by $0.30 \%$ which clearly show the dominance of positive effect is more than the negative one. Again, both the positive and negative shocks of STOCKP have significant effect on $R_{0} A_{R}$, showing that a $1 \%$ increase in STOCKP will increase the ROA by $0.16 \%$ while $1 \%$ decrease in STOCKP will increase the $R O A_{R}$ by $0.36 \%$ a dominance of negative shocks over the positive one.

In the short-run $\left(R O A_{J}\right)$, both positive and negative changes of OILP have significant impact on $R O A$, suggesting that a $1 \%$ increase in OILP will increase the ROA by $0.01 \%$ but $1 \%$ decrease in OILP will increase the ROA by $0.01 \%$. On the other hand, the positive and negative shocks of STOCKP have significant impact on $\mathrm{ROA}$, with the dominance of the latter one, implying that $1 \%$ increase in STOCKP will increase the ROA, by $0.003 \%$ but $1 \%$ decrease in OILP will increase the ROA, by $0.005 \%$. Besides, RGDP has significant impact 
Amin | Asymmetric Impact of Oil Prices and Stock Prices on Bank's Profitability: Evidence from Saudi Islamic Banks

on both $R O A_{R}$ and $R O A_{J}$, and the magnitude of the impact is observed higher $(2.75 \%)$ in case of ROAR than (1.87\%) for the ROA.

The coefficient of the error correction term (ECT) of ROA $A_{R}$ and ROA $43 \%$ and $-74 \%$ indicating that market disequilibrium is adjusted at a speed of $43 \%$ and $74 \%$ per period, respectively. In other words, the mark equilibrium is achieved within one and half year to two years.

\subsubsection{Long-run Relation}

The long-run cointegrating equations are presented in table 8 and table 9 which are based on the estimated NARDL results of tables 6 and 7. Table 8 displays the long-run relations of ROE with the exogenous variables. In the long-run, there is both positive and negative significant impact of OILP on ROE, with the dominance of latter over the earlier one, in contrast to $\mathrm{ROE}_{\mathrm{R}}$ where OILP has no significant impact. It indicates that $1 \%$ increase in OILP is related to the increase in ROE, by $0.004 \%$, and $1 \%$ decrease in OILP is associated to the increase in ROE, by $5.78 \%$, assuming the influence of other variables constant. Moreover, there is both positive and negative impact of STOCKP on $\mathrm{ROE}_{\mathrm{R}}$ with the dominance of latter implying that that $1 \%$ increase in STOCKP is related to the increase in $\mathrm{ROE}_{\mathrm{R}}$ by $7.433 \%$, and $1 \%$ decrease in STOCKP is associated to the decrease in $\mathrm{ROE}_{\mathrm{R}}$ by $0.002 \%$, assuming the effect of other variables constant. On the other side, there is only negative and significant impact of STOCKP on ROE indicating that $1 \%$ decrease in STOCKP is linked to the decrease in ROE, by $0.01 \%$, assuming the outcome of other variables constant. In addition, RGDP has positive and significant impact on the ROE, showing that $1 \%$ increase in RGDP is related to the increase in ROE by $0.353 \%$. This result is consistent with Athanasoglou et al. (2008) Dietrich and Wanzenried (2014b).

Table 8. Long-run Relation Based on ROE

\begin{tabular}{|c|c|c|c|c|c|c|c|c|}
\hline \multirow[b]{2}{*}{ Variable } & \multicolumn{4}{|c|}{$\mathrm{ROE}_{\mathrm{R}}$} & \multicolumn{3}{|c|}{$\mathrm{ROE}_{\mathrm{J}}$} & \multirow[b]{2}{*}{ Decision } \\
\hline & Coeff & F-stat & P-value & Decision & Coeff & F-stat & $\mathrm{P}$-value & \\
\hline RGDP(-1) & 0.218 & 0.082 & 0.780 & Absence & 0.353 & 1.966 & 0.011 & Presence \\
\hline OILP_POS & 841 & 1.527 & 0.245 & Abs & 0.004 & 0.097 & 0.021 & ence \\
\hline OILP_NEG & 9.168 & 0.001 & 0.971 & & -5.780 & 12.047 & 0.006 & Presence \\
\hline STOCKP_POS & 7.433 & 25.097 & 0.002 & Presence & -7.454 & 1.676 & 0.120 & ence \\
\hline STOCKP_NEG(-1) & 0.002 & 18.338 & 0.002 & Presence & 0.006 & 9.085 & 0.013 & 3 Presence \\
\hline
\end{tabular}

Note: The long-run relation is obtained by $\theta_{1}=-\beta_{1} / \beta_{0}, \theta_{2}=-\beta_{2} / \beta_{0}, \theta_{3}=-\beta_{3} / \beta_{0}, \theta_{4}=-\beta_{4} / \beta_{0}$, for positive and negative shocks of the OILP and STOCKP, respectively. The subscript $R$ and I stand for Alrajhi Bank and Aljazira Bank, respectively. Superscript *,**, and ${ }^{* * *}$ indicate the rejection of the null hypothesis at $10 \%$, $5 \%$, and $1 \%$, respectively.

Table 9 shows the long-run relations of ROA with the exogenous variables. In the long-run, positive and negative shocks of OILP have significant impact on both $\mathrm{ROA}_{\mathrm{R}}$ and $\mathrm{ROA}$. It suggests that a $1 \%$ increase in OILP will increase the $\mathrm{ROA}_{R}$ by $3.604 \%$ and will increase ROA, by $0.020 \%$ whereas $1 \%$ decrease in 
Amin | Asymmetric Impact of Oil Prices and Stock Prices on Bank's Profitability: Evidence from Saudi Islamic Banks

OILP will increase the ROA ${ }_{R}$ by $0.862 \%$. and will increase ROA, by $0.001 \%$, assuming the effect of others constant. Again, the positive and negative shocks of STOCKP have significant impact on $\mathrm{ROA}_{R}$ but only negative shock of STOCKP has significant impact on ROA. It implies that a $1 \%$ increase in STOCKP will increase the $\mathrm{ROA}_{R}$ by $0.27 \%$ whereas $1 \%$ decrease in STOCKP will increase the $R_{0} A_{R}$ by $0.31 \%$ and will increase the ROA, by $0.03 \%$, with the assumption of ceteris paribus. Moreover, RGDP has significant impact on ROA implying that a $1 \%$ increase in GDP will increase the ROA, by $2.51 \%$.

Table 9. Long-run Relation Based on ROA

\begin{tabular}{|c|c|c|c|c|c|c|c|c|}
\hline \multirow[b]{2}{*}{ Variable } & \multicolumn{4}{|c|}{$\mathrm{ROA}_{R}$} & \multicolumn{4}{|c|}{$\mathrm{ROA}_{\mathrm{J}}$} \\
\hline & Coeff & F-stat & P-value & Decision & Coeff & F-stat & P-value & Decision \\
\hline RGDP(-1) & 14.54 & 0.064 & 0.813 & Absence & 2.513 & 17.696 & 0.006 & Presence \\
\hline OILP_POS(-1) & 3.604 & 36.038 & 0.004 & Presence & 0.020 & 18.544 & 0.005 & Presence \\
\hline OILP_NEG(-1) & -0.862 & 42.077 & 0.003 & Presence & -0.001 & 28.445 & 0.002 & Presence \\
\hline STOCKP_POS & 0.270 & 15.513 & 0.01 & Presence & 0.004 & 0.1070 & 0.755 & Absence \\
\hline STOCKP_NEG(-1) & 0.314 & 102.82 & 0.000 & Presence & 0.033 & 33.855 & 0.001 & Presence \\
\hline
\end{tabular}

Note: The long-run relation is obtained by $\theta_{1}=-\beta_{1} / \beta_{0}, \theta_{2}=-\beta_{2} / \beta_{0}, \theta_{3}=-\beta_{3} / \beta_{0}, \theta_{4}=-\beta_{4} / \beta_{0}$, for positive and negative shocks of the OILP and STOCKP, respectively. The subscript $R$ and I stand for Alrajhi Bank and Aljazira Bank, respectively. Superscript *, **, and ${ }^{* * *}$ indicate the rejection of the residuals null at $10 \%$, $5 \%$, and $1 \%$, respectively

\subsubsection{Asymmetric Relationships}

The Wald test statistics are applied to detect the long-run and short-run asymmetric relations with the null hypothesis of symmetry. Table 10 shows the absence of both long-run and short-run asymmetric relations of OILP and STOCKP in the case ROEJ, and there exist only long-run asymmetric relations of OILP for ROER. In contrast, long-run asymmetric relations of OILP and STOCKP with ROA exist in the case of both models. Again, this study confirms short-run asymmetric relations of OILP and STOCKP with ROA . while this relation of STOCKP presence with ROAJ.

Table 10. Wald test for Long-run and Short-run Asymmetry

\begin{tabular}{|c|c|c|c|c|c|c|c|c|}
\hline \multirow[b]{3}{*}{ Variable } & \multicolumn{2}{|c|}{$\mathrm{ROE}_{\mathrm{R}}$} & \multicolumn{2}{|c|}{$\mathrm{ROE}_{\mathrm{J}}$} & \multicolumn{4}{|c|}{$\mathrm{ROA}_{\mathrm{R}}$} \\
\hline & \multicolumn{4}{|c|}{ Long-run asymmetry } & \multicolumn{4}{|c|}{ Long-run asymmetry } \\
\hline & F-stat & P-value & F-stat & P-value & F-stat & P-value & F-stat & P-value \\
\hline$\overline{\mathrm{OILP}}$ & 2.999 & 0.059 & 1.508 & 0.248 & 16.059 & 0.016 & 79.029 & 0.000 \\
\hline \multirow[t]{2}{*}{ STOCKP } & 1829 & 0.3839 & 0.057 & 0.815 & 64.826 & 0.016 & 17.800 & 0.006 \\
\hline & \multicolumn{4}{|c|}{ Short-run asymmetry } & \multicolumn{4}{|c|}{ Short-run asymmetry } \\
\hline OILP & 0.199 & 0.1409 & 0.508 & 0.142 & 79.756 & 0.001 & 1.007 & 0.354 \\
\hline STOCKP & 0.249 & 0.123 & 0.571 & 0.752 & 28.988 & 0.006 & 65.402 & 0.000 \\
\hline
\end{tabular}

Note: The subscript R and J stand for Alrajhi Bank and Aljazira Bank, respectively. Superscript *, $* *$, and ${ }^{* * *}$ indicate the rejection of the residuals null at $10 \%, 5 \%$, and $1 \%$, respectively. 
Amin $\mid$ Asymmetric Impact of Oil Prices and Stock Prices on Bank's Profitability: Evidence from Saudi Islamic Banks

\subsubsection{Asymmetric Adjustment Process}

Figure 4-8 exhibit the cumulative dynamic asymmetric multiplier outcome for a total of 15 years with the reaction of ROE and ROA on the positive and negative changes in STOCKP and OILP. The solid black line shows the adjustment process of ROE and ROA with the positive and negative changes in STOCKP and OILP while the light dash red line which also known as the asymmetric line is situated between lower and upper band under the area of 95\% confidence interval. The general rule of detecting the presence of asymmetric relation between the variables is that the zero straight line must crosses between the two boundary (lower and upper) which also indicate the statistically significant result.

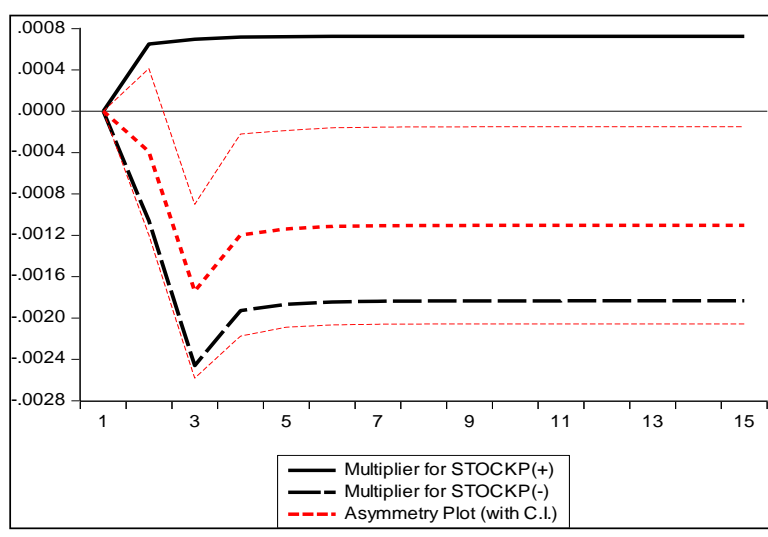

Figure 4. ROE $_{R}-S T O C K P$

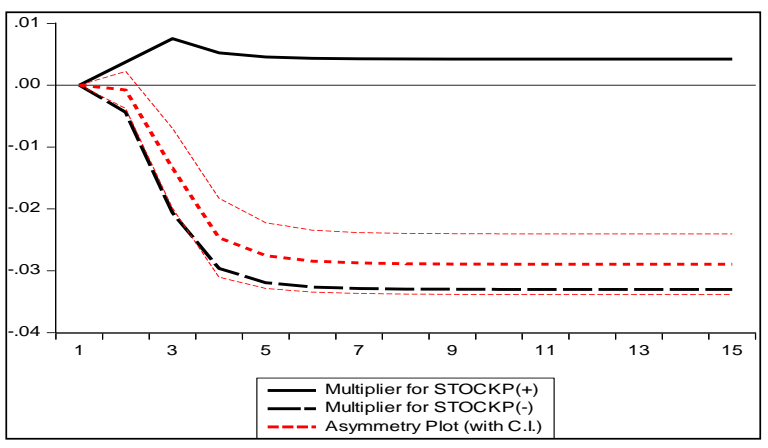

Figure 6. ROAJ - STOCKP

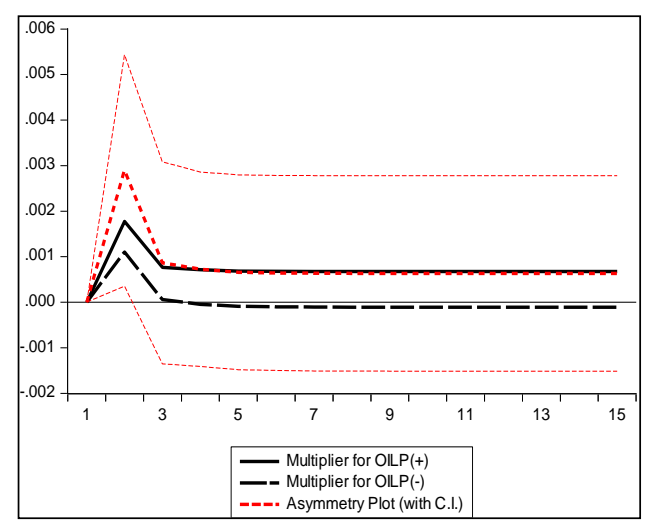

Figure 5. ROER -OIL

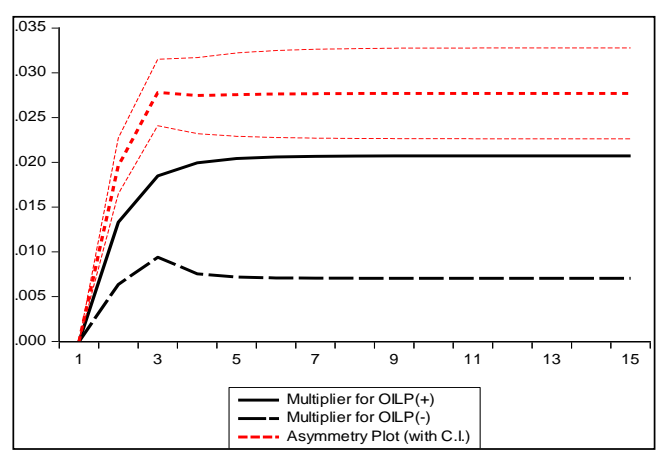

Figure 7. ROAJ - OILP

Figure 4- figure 7 present the scenario which is in line with the findings reported in table 10. The cumulative dynamic asymmetric multiplier graphs (Figure4 - Figure 7) shows that the effect of positive and negative change of STOCKP and OILP on ROA and ROE takes around 3-4 years to achieve long-run equilibrium. 
Amin $\mid$ Asymmetric Impact of Oil Prices and Stock Prices on Bank's Profitability: Evidence from Saudi Islamic Banks

\subsection{Robustness Check}

Since NARDL model follow the same assumptions as Ordinary Least Squared (OLS) model, it is important to check the assumptions of residuals. The residuals are to be free from normality issue, serial correlation and heteroscedastic distribution. In addition, all the models are to be rightly specified. As can be observed from tables 4.5 and 4.6, the residuals from all the estimated NARDL models have no serial correlation, with normal and homoscedastic distribution as evident from Breusch-Godfrey LM test, JarqueBera test and White test, respectively. Moreover, the Ramsay reset test indicates that all the models have exact functional forms. At the last stage of model diagnostics, the CUSUM and CUSUMSQ tests are conducted as suggested by Pesaran (1997) for checking the NARDL models' stability which are presented in Figure 8 and Figure 9.
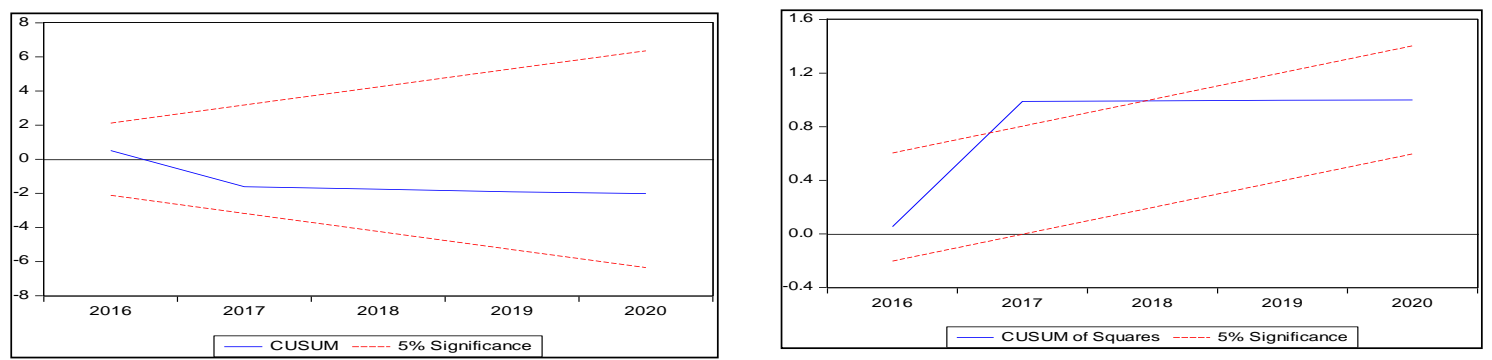

Figure 8. $R_{R} E_{R}, R G D P$ OILP, STOCKP
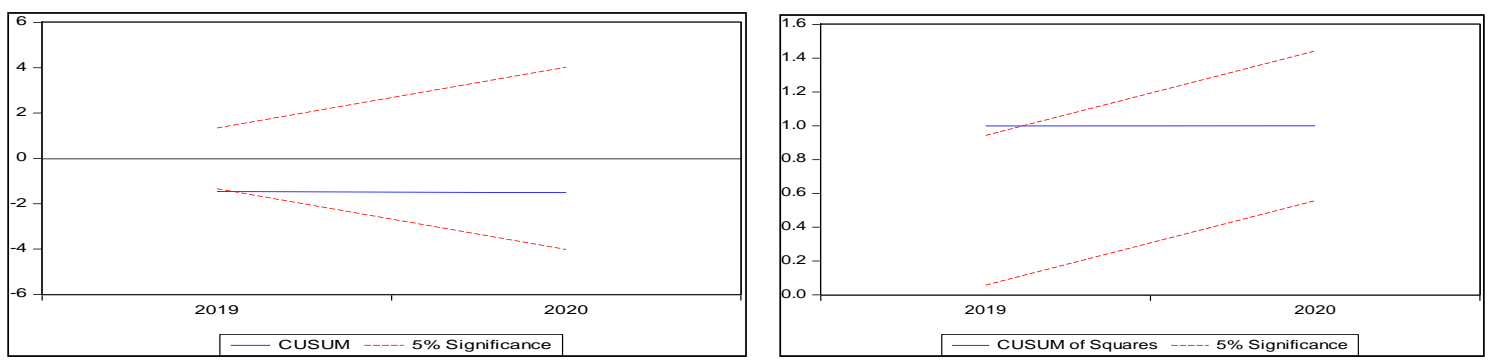

Figure 9. ROAR, RGDP OILP, STOCKP
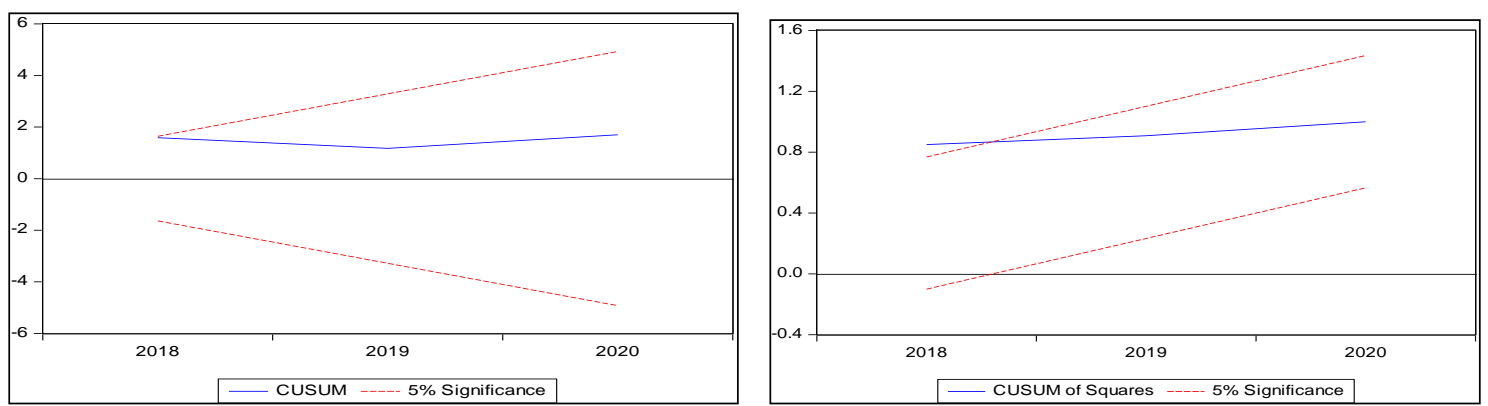

Figure 10. ROE 
Amin | Asymmetric Impact of Oil Prices and Stock Prices on Bank's Profitability: Evidence from Saudi Islamic Banks
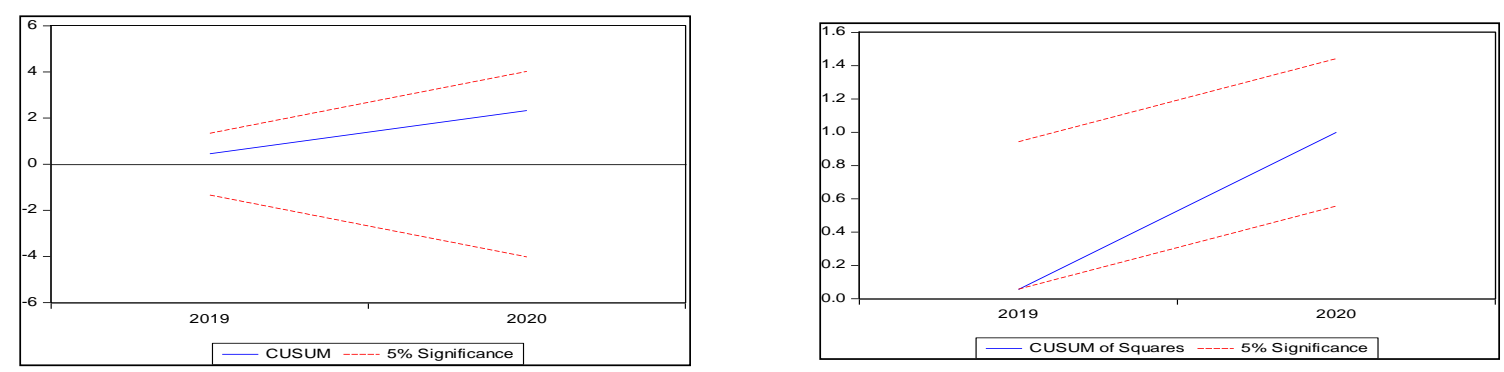

Figure 11. ROA, RGDP OILP, STOCKP

\subsection{Analysis}

As discussed in previous section, the higher oil prices and stock prices lead to increase the two Islamic banks' profitability in Saudi Arabia. As an oilexporting country, Islamic banks enjoys the benefit of higher oil prices. The banks are inclined to make investment decisions on the oil-based projects. Besides, Islamic banks' stock prices are generally affecting their profitability. This is because of the development of Saudi financial sector ensures a sound and well-functioning stock market with easy and available information helpful for financial institutions like banks to assess potential risk and make right investment decision. Saudi Islamic banks have created higher confidence level among the investors and it also provides them lucrative dividends. As a result, Islamic banks' stock prices become higher over the years which lead to gain higher profitability in terms of ROA and ROE. Lastly, the positive link between real GDP growth with the profitability of Islamic Banks' which is confirmed by this study indicate that economic growth flourish Islamic banking sector by creating higher demand for Islamic banking product and services both in the short-run and long-run. In past few years, economic growth along with national development plan enable financial institutions particularly Islamic banks to take part in diversified investment projects to achieve Saudi Vision 2030.

\section{Conclusion and Policy Recommendations}

\subsection{Conclusion}

This study examines the asymmetric impact of oil prices and stock prices on two largest Islamic banks' profitability for the period 2000-2020. It considers two determinates of banks' profitability i.e., ROE and ROA which are affected the three external factors such as oil prices, stock prices and real GDP. It applies a nonlinear autoregressive distributed lag nonlinear autoregressive distributed lag (NARDL) model to achieve the objective. 
Amin | Asymmetric Impact of Oil Prices and Stock Prices on Bank's Profitability: Evidence from Saudi Islamic Banks

In the case of ROE, the short-run negative shocks of OILP have significant impact on both $\mathrm{ROE}_{R}$, where positive shocks dominate over the negative one, and ROE, where positive shocks of OILP has no impact and negative shock of OILP has significant impact on ROEJ. On the other hand, positive shocks of STOCKP has no impact on $\mathrm{ROE}_{R}$, but negative shock of STOCKP has significant impact on $\mathrm{ROE}_{\mathrm{R}}$. Both positive and negative shocks in STOCKP have significant impact on ROEj. In the case of both models, RGDP has significant impact on $\mathrm{ROE}_{\mathrm{R}}$ and ROEJ.

In the case of ROE, the long-run positive and negative shocks of OILP have significant impact of on $\mathrm{ROE}_{\text {J }}$ with the dominance of latter one, in contrast to ROE $R$ where OILP has no significant impact. Besides, both positive and negative shocks of STOCKP have significant impact on $\mathrm{ROE}_{R}$ with the dominance of latter, however, only negative shocks of STOCKP have significant impact on $\mathrm{ROE}_{\mathrm{J}}$. In this study, the long-run and short-run asymmetric relations of OILP and STOCKP are not confirmed in the case ROE whereas the long-run asymmetric relations of only OILP is confirmed for ROE . $_{\text {. }}$ The study also finds that RGDP has positive and significant impact on the ROEs in the long-run.

In the case of ROA, the short-run positive and negative shocks of OILP have significant influence on both $\mathrm{ROA}_{R}$, where the dominance of positive effect is more than the negative one, and ROA, where the changes in both effect are the same. On the other hand, the positive and negative shocks of STOCKP have significant effect on both $R O A_{R}$ and $R O A$, showing a dominance of negative shocks over the positive one. Besides,_RGDP has significant impact on both $R O A_{R}$ and $R O A_{J}$.

In the case of ROA, the long-run positive and negative shocks of OILP have significant impact on both $R O A_{R}$ and ROA. Besides, positive and negative shocks of STOCKP have significant impact in the case of ROA $A_{R}$ while only negative shock of STOCKP has significant impact on ROA.

In this study, the long-run and short-run asymmetric relations of OILP and STOCKP are not confirmed in the case $\mathrm{ROE}_{\mathrm{J}}$, whereas the long-run asymmetric relations of OILP is only confirmed for $\mathrm{ROE}_{R}$. On the other hand, the long-run asymmetric relations of OILP and STOCKP is established for both ROA $A_{R}$ ad $R O A$, while the short-run asymmetric relations of OILP and STOCKP is confirmed with ROA $A_{R}$ and STOCKP with ROA.

Based on the above finding, it is clear that OILP and STOCKP have significant role in determining the Islamic banks' profitability in Saudi Arabia. Although both positive and negative shocks of OILP and STOCKP are significant in most cases, the higher oil prices and higher stock prices are observed to be 
Amin $\mid$ Asymmetric Impact of Oil Prices and Stock Prices on Bank's Profitability: Evidence from Saudi Islamic Banks

dominant factors affecting the profitability of two largest Islamic banks in Saudi Arabia. In addition, real GDP growth as an important external factor affect the Islamic banks' profitability.

\subsection{Recommendation}

A few policy recommendations are provided based on the empirical analysis. The findings of this study recommends that policymakers should pay attention to increase the sound and development and efficiency of Saudi stock market to achieve the higher profitability of Islamic banking sectors which may attract foreign investments and boost the Saudi economy. This finding is also important for the portfolio managers to make decision on acquiring Islamic banks' stock. It would be profitable to buy Islamic banks' stock when the trend of oil prices is higher. Besides, macroeconomic policy should focus economic diversification for preparing any external shocks in the global market. Based on the evidence of this study that any negative shock of oil prices will affect Islamic banks' profitability, the management of Islamic banks need to pay attention of the risk assessment, market monitoring, and particularly tying Islamic banking capitalization to oil price and stock price shocks might help facing the market fluctuation as these two factors affect their profitability. Since oil price is one of the key determinants of Saudi Islamic banks' profitability, there is an urgent need for strategic policy to absorb any future shocks. In this regard, Islamic banks can play a pivotal role and support the government to effectively implement the Saudi economic diversification plan termed as Saudi Vision 2030. Saudi Islamic banks and other related financial institutions need to diversify their investment portfolios into more productive and export oriented sectors. These institutions can invest more on Small and Medium Enterprises (SMEs) to help achieve higher efficiency, productivity, and competitiveness of the industries. Thus, the diversified investments policy of Islamic financial institutions into private sector can not only facilitate rapid growth of export oriented high-value added industries but also generate huge employment opportunities and attract foreign investment in transport, communication, tourism, IT and other manufacturing industries. This study suggests that any future study can be conducted in identifying the internal factors of Islamic as well as conventional banks' profitability and economic diversification with panel data analysis in Saudi Arabia. 
Amin | Asymmetric Impact of Oil Prices and Stock Prices on Bank's Profitability: Evidence from Saudi Islamic Banks

\section{References}

Alaagam, A. (2019). The relationship between profitability and stock prices: Evidence from the Saudi Banking Sector. Research Journal of Finance Accounting, 10, 91-101.

Albertazzi, U., \& Gambacorta, L. (2009). Bank profitability and the business cycle. Journal of financial stability, 5(4), 393-409. doi:10.1016/j.jfs.2008.10.002

Albertazzi, U., \& Gambacorta, L. (2009). Bank profitability and the business cycle Journal of Financial Stability, 5(5), 393-409.

Alkhareif, R. J. F. R. L. (2016). Are there significant premiums in the Saudi stock market?, 18, 108-115.

Allen, F., \& Gale, D. J. J. o. f. i. (1999). Diversity of opinion and financing of new technologies. 8(1-2), 68-89.

Anwar, M., \& Herwany, A. (2006). The determinants of successful bank profitability in Indonesia: empirical study for provincial government's banks and private non-foreign banks. Retrieved from http://ssrn.com/abstract=1670707

Arora, H., \& Arora, P. (2013). Effect of investments in information technology on bank performance: empirical evidence from Indian public sector banks. International Journal of Business Information Systems, 13(4), 400-417.

Athanasoglou, P. P., Brissimis, S. N., \& Delis, M. D. (2008). Bank-specific, industry-specific and macroeconomic determinants of bank profitability. Journal of international financial markets, institutions \& money, 18(2), 121-136. doi:10.1016/j.intfin.2006.07.001

Beck, T., Demirgüç-Kunt, A., \& Levine, R. (1999). A new database on financial development and structure [e-book]. Retrived from https://elibrary.worldbank.org/doi/pdf/10.1596/1813-9450-2146.

Beck, T., Demirgüç-Kunt, A., \& Merrouche, O. (2010). Islamic vs. conventional banking: Business model, efficiency and stability [e-book]. Retrived from https://elibrary.worldbank.org/doi/abs/10.1596/1813-94505446.

Beckmann, R. (2007). Profitability of Western European banking systems: Panel evidence on structural and cyclical determinants. SSRN Electronic Journal. doi:10.2139/ssrn.1090570.

Ben Ameur, I., \& Mhiri, S. (2013). Explanatory factors of bank performance evidence from Tunisia. International Journal of Economics, Finance and Management, 2(1), 1-11. 
Amin | Asymmetric Impact of Oil Prices and Stock Prices on Bank's Profitability: Evidence from Saudi Islamic Banks

Ben Naceur, S., \& Omran, M. (2011). The effects of bank regulations, competition, and financial reforms on banks' performance. Emerging Markets Review, 12(1), 1-20.

Bloomberg L.P. (2021). Return on Asset, Return of Equity, Stock price, oil price, real GDP from 2000 to 2020. Retrieved from https://www.bloomberg.com/asia.

Broock, W. A., Scheinkman, J. A., Dechert, W. D., \& LeBaron, B. (1996). A test for independence based on the correlation dimension. Econometric reviews, 15(3), 197-235. doi:10.1080/07474939608800353

Davydenko, A. (2011). Determinants of bank profitability in Ukraine. Undergraduate Economic Review, 7(1), 1-30. .

Demirgüç-Kunt, A., \& Huizinga, H. (1999). Determinants of commercial bank interest margins and profitability: some international evidence. The World Bank Economic Review, 13(2), 379-408.

Dickey, D. A., \& Fuller, W. A. (1979). Distribution of the estimators for autoregressive time series with a unit root. Journal of the American Statistical Association, 74(366), 427. doi:10.2307/2286348

Dietrich, A., \& Wanzenried, G. (2014a). The determinants of commercial banking profitability in low-, middle-, and high-income countries. $Q$. Rev. Econ. Finance, 54, 337-354.

Dietrich, A., \& Wanzenried, G. (2014b). The determinants of commercial banking profitability in low-, middle-, and high-income countries. The Quarterly review of economics and finance, 54(3), 337-354. doi:10.1016/j.gref.2014.03.001

Eichengreen, B., \& Gibson, H. D. (2001). Greek banking at the dawn of the new millennium. In Discussion Paper 2791. London: CEPR.

Essayyad, M., \& Madani, H. (2003). Investigating bank structure of an open petroleum economy: The case of Saudi Arabia. Managerial Finance.

Fitchratings. (2021). Saudi Islamic Banks: 2020 Results Dashboard. Retrieved from https://www.fitchratings.com/research/islamic-finance/saudiislamic-banks-2020-results-dashboard-30-03-2021,

Flamini, V., McDonald, C., \& Schumacher, L. (2009). The determinants of commercial bank profitability in sub-Saharan Africa. Retrieved from http://dx.doi.org/10.5089/9781451871623.00

Gulati, R., \& Kumar, S. (2016). Assessing the impact of the global financial crisis on the profit efficiency of Indian banks. Economic modelling, 58, 167181. doi:10.1016/j.econmod.2016.05.029 
Amin | Asymmetric Impact of Oil Prices and Stock Prices on Bank's Profitability: Evidence from Saudi Islamic Banks

Habibullah, M. S., \& Eng, Y.-K. (2006). Does financial development cause economic growth? A panel data dynamic analysis for the Asian developing countries. Journal of the Asia Pacific Economy, 11(4), 377393.

Hassan, M., Amin, M. F. B., Khokhar, I., \& Khan, M. N. (2020). Examining the Comparative Efficiency of GCC Islamic Banking. Journal of Islamic Banking \& Finance, 37(4), 9-32.

Hassan, M., Khan, M. N., Amin, M. F. B., \& Khokhar, I. (2018). Measuring the Performance of Islamic Banks in Saudi Arabia. International Journal of Economics Management, 12(1).

Hassan, M. A., Hafsa, N., \& Muhammad, I. (2011). Islamic banking insulation against US credit crisis. International Journal of Business Social Science, 2(10), 193-205.

Hassan, M. K., \& Bashir, A. H. M. (2003). Determinants of Islamic banking profitability. Paper presented at the 10th ERF annual conference, Morocco.

Hesse, H., \& Poghosyan, T. (2009). Oil Prices and bank performance: Evidence from major oil-exporting countries in the Middle East and North Africa. $\quad$ Retrieved from https://www.imf.org/en/Publications/WP/Issues/2016/12/31/OilPrices-and-Bank-Profitability-Evidence-From-Major-Oil-ExportingCountries-in-the-Middle-23337

Kaya, T. Y. (2002). Determinants of profitability in Turkish banking sector. Retrieved from http://www.bddk.org.tr/websitesi/English.aspx

Khan, M. N., Amin, M. F. B., Khokhar, I., Hassan, M., \& Ahmad, K. (2018). Efficiency measurement of islamic and conventional banks in Saudi Arabia: an Empirical and comparative analysis. Al-Shajarah: Journal of the International Institute of Islamic Thought(Special), 111-134.

Khokhar, I., Hassan, M., Khan, M. N., \& Amin, M. F. B. (2020). Investigating the efficiency of GCC banking sector: An empirical comparison of islamic and conventional banks. International Journal of Financial Research, 11(1).

King, R. G., \& Levine, R. (1993). Finance and growth: Schumpeter might be right. The quarterly journal of economics, 108(3), 717-737.

Kosmidou, K. (2008). The determinants of banks' profits in Greece during the period of EU financial integration. Managerial Finance. 34(3). 146159.

Kpodar, K., \& Imam, P. A. (2010). Islamic banking: how has it diffused?. IMF Working Paper. 
Amin | Asymmetric Impact of Oil Prices and Stock Prices on Bank's Profitability: Evidence from Saudi Islamic Banks

Lee, C., \& Hsieh, M. (2013). The impact of bank capital on profitability and risk in Asian banking. Journal of international money and finance, 32, 251281. doi:10.1016/j.jimonfin.2012.04.013

Levine, R., \& Zervos, S. J. A. e. r. (1998). Stock markets, banks, and economic growth. The American Economic Review, 88(3). 537-558.

Muhamad, M., Amir, S., \& Abdelhakim, E. (2013). Comparative analysis of profitability determinants of domestic and foreign islamic banks in Malaysia. International journal of economics and financial issues, 3(3), 559-569.

Naceur, S. B., \& Goaied, M. (2008). The determinants of commercial bank interest margin and profitability: Evidence from Tunisia. Frontiers in Finance Economics, 5(1), 106-130.

Perron, P. (1989). The Great crash, the oil price shock, and the unit root hypothesis. Econometrica, 57(6), 1361-1401. doi:10.2307/1913712

Pesaran, M. H., Shin, Y., \& Smith, R. J. (2001). Bounds testing approaches to the analysis of level relationships. 16(3), 289-326. doi:https://doi.org/10.1002/jae.616

Pesaran, M. H., Shin, Y., \& Smith, R. P. (1999). Pooled mean group estimation of dynamic heterogeneous panels. Journal of the American statistical Association, 94(446), 621-634.

Priscilla, I. C., \& Ezeanyeji, C. I. (2019). Financial development and economic growth nexus in Nigeria. International Journal of Business Management Invention, 8(3), 50-63.

Rivard, R. J., \& Thomas, C. R. (1997). The effect of interstate banking on large bank holding company profitability and risk. Journal of Economics Business, 49(1), 61-76.

Rosly, S. A., \& Bakar, M. A. (2003). Performance of Islamic and mainstream banks in Malaysia. International Journal of Social Economics. 30(12). 1249-1265. DOI 10.1108/03068290310500652

Rossi, S., Borroni, M., Lippi, A., \& Piva, M. (2018). Determinants of Bank Profitability in the Euro Area: What Has Changed During the Recent Financial Crisis? International business research (Toronto), 11(5), 18. doi:10.5539/ibr.v11n5p18

Sharma, E., \& Mani, M. (2012). Impact of macroeconomic and financial market indicators on the banking sector: Some evidence from India. International Journal of Research in Finance Marketing, 2(2), 171-185.

Sharma, P., Gounder, N., \& Xiang, D. (2013). Foreign banks, profits, market power and efficiency in PICs: some evidence from Fiji. Appl. Financ. Econ., 23. 
Amin | Asymmetric Impact of Oil Prices and Stock Prices on Bank's Profitability: Evidence from Saudi Islamic Banks

Shin, Y., Yu, B., \& Greenwood-Nimmo, M. (2011). Modelling Asymmetric Cointegration and Dynamic Multiplier in a Nonlinear ARDL Framework, Mimeo.

Shin, Y., Yu, B., \& Greenwood-Nimmo, M. (2014). Modelling asymmetric cointegration and dynamic multipliers in a nonlinear ARDL framework. In Festschrift in honor of Peter Schmidt (pp. 281-314): Springer.

Staikouras, C. K., \& Wood, G. E. (2004). The determinants of European bank profitability. International Business Economics Research Journal, 3(6).

General Autority of Statistics. (2020). Retrieved from https://www.stats.gov.sa/en

Sufian, F. (2009). Factors influencing bank profitability in a developing economy: Empirical Evidence from Malaysia. Global Business Review, 10(2), 225-241.

Sufian, F., \& Habibullah, M. S. (2010). Assessing the impact of financial crisis on bank performance: Empirical evidence from Indonesia. ASEAN Economic Bulletin, 245-262.

Suhad, A., \& Tahar, T. (2021). Determinants of financing in emerging markets in Saudi Arabia. PalArch's Journal of Archaeology of Egypt / Egyptology, 18(13), 1130-1136.

Tan, Y., \& Floros, C. (2012). Bank profitability and GDP growth in China: a note. Journal of Chinese Economic and Business Studies. 10(3)._267-273, DOI: 10.1080/14765284.2012.703541

Tlemsani, I., \& Al Suwaidi, H. (2016). Comparative analysis of Islamic and conventional banks in the UAE during the financial crisis. Asian Economic and Financial Review, 6(6), 298.

Tzeremes, N. G. (2015). Efficiency dynamics in Indian banking: A conditional directional distance approach. European journal of operational research, 240(3), 807-818. doi:10.1016/j.ejor.2014.07.029

Yanikkaya, H., Gumus, N., \& Pabuccu, Y. (2018). How profitability differs between conventional and Islamic banks: A dynamic panel data approach. Pacific-Basin Finance Journal, 48, 99-111.

Zantioti, L. E. (2009). Does Islamic bank performance differ by region. Unpublished Master's Thesis, Stockholm School of Economics, Sweden.

Zeitun, R. (2012). Determinants of Islamic and Conventional Banks performance in GCC countries using panel data analysis. Global Economy and Finance Journal, 5(1), 53-72. 
Amin $\mid$ Asymmetric Impact of Oil Prices and Stock Prices on Bank's Profitability: Evidence from Saudi Islamic Banks

Zivot, E., \& Andrews, D. W. K. (1992). Further evidence on the great crash, the oil-price shock, and the unit-root hypothesis. Journal of business \& economic statistics, 10(3), 251-270. doi:10.1080/07350015.1992.10509904. 
Amin Asymmetric Impact of Oil Prices and Stock Prices on Bank's Profitability: Evidence from Saudi Islamic Banks

This page is intentionally left blank.

International Journal of Islamic Economics and Finance (IJIEF), 5(1), 31-58 58 